\section{Learning Outcomes:}

Participants will be able to:

1. Learn how to contact and use the new, amazingly fast and efficient internet relay service available in Saipan and other parts of the United States and the role of the relay operator in assisting clients with relay calls for persons who are Deaf, Hard of Hearing, and 21st Century features such as Voice Carry Over, Deaf-Blind, and Speech Disabled services.

2. Learn three differences between a natural, visually based-language with conceptually accurate signs and facial grammar and an arbitrarily created signed form of a spoken language.

\section{DIAMOND HALL}

Instructional Principles for Training Students to Use Assistive Technology

Eric Morrison, M.A., Lead Faculty

Disabled Student Resources

Pima County Community College, Tuczon, Arizona

\section{Abstract}

This session will focus on the importance of effective training and basic principles for teachng students to use Assisitve Technologies (AT). Pre-assessment of student needs and abilities will be discussed. Handouts will outline instructional guidelines, ways of reducing cognitive demands during learning, and conceptual ways to teach AT functions that help to limit student confusion. Methods for assessing outcomes and student perceptions will also be included.

\section{Learning Outcomes:}

\section{Participants will be able to:}

1. Learn the basic principles for teaching students to use Assistive Technology

2. Learn pre-assessment of students needs and abilities.

\title{
GENERAL SESSIONS
}

Friday, November 22, 2002

(1:00 pm to $2: 30 \mathrm{pm}$ )

\section{HIBISCUS ROOM - A}

Assistive Technology: Classroom Tools for Reading. Writing and Math

Jill S. Oberstein, M.A., OTR/L, Project Director (Assistive Technology Access Program)

\section{Abstract}

Students with learning disabilities don't always appear to be disabled to the casual observer, but their hidden disabilities have a significant negative impact on educational outcomes. This presentation will explore how the use of a range of assistive technologies combined with educational strategies can make a substantial difference in academic success related to reading, writing and math for students with a variety of learning disabilities.

\section{Learning Outcomes:}

1. Identify a continuum of low to high tech assistive technology tools and strategies that can bed used to support and enhance academic performance related to reading, writing and mathematics.

2. Understand the application of assistive technology for both remediation and compensatory skills.

\section{HIBISCUS ROOM - B}

Section $\mathbf{5 0 8}$ of Rehabilitation Act and other Disability - Related Laws in Assistive Technology Brian Shaughnessy, Attorney-at-Law (Honolulu, Hawaii)

\section{Abstract}

In 1998, Congress amended the Rehabilitation Act and strengthened provisions covering access to information in the Federal sector for people with disabilities. As amended, Section 508 of the Rehabilitation Act requires access to the Federal government's electronic and information technology. 
American with Disabilities Act

Act prohibits discrimination against individuals with disabilities in employment, housing, education, and access to public services. The ADA defines a disability with a broad legal definition.

\section{Individuals with Disabilities Education Act}

Requires public schools to make available to all eligible children with disabilities a free appropriate public education in the least restrictive environment according to their needs.

\section{Rehabilitation Act}

other sections

\section{Fair Housing Act \\ other sections}

\section{Fair Housing Act}

Makes it unlawful to discriminate in any aspect of selling, renting, or denying housing because of an individual's disability. Owners are further required to make reasonable exceptions in their housing

\section{Air Carrier Access Act}

Air carriers are prohibited, in theory, from discrimination against qualified individuals with physical and/or mental impairments.

\section{Learning Outcomes:}

\section{Participants will be able to:}

1. Learn the requirements of Federal government to make electronic and information technology accessible to people with disability.

2. Learn the different laws related to Assistive Technology.
HIBISCUS - C

Center for Services Your One Stop Shop for Medical Equipment \& Supplies

Gia B. Ramos, R.N., B.SN, Director of Healthcare Specialist

\section{Abstract}

The presenter will discuss the guidelines for Medicare beneficiaries and other major private Insurance Companies for signature requirements. She will also discuss the Medicare updates and Diabetic Awareness. Some latest devices for people with Diabetes will be discussed.

\section{Learning Outcomes:}

Participants will be able to:

1. Be educated on the devices used by people with Diabetes.

2. Have knowledge on consumer's guidelines on expediting documentation for accurate services.

\section{DIAMOND HALL}

Alternative Financing Program for Assistive Technology (Live Video Teleconference)

Dr. Joey Wallace, Policy Analyst \& Funding Specialist, Virginia Commonwealth University, Richmond, Virginia.

\section{Abstract}

This presentation will provide an overview of Assistive Technology Loan Financing programs and the difference they can make in the lives of individuals with disabilities. Discussion will include best practices and charateristics of successful programs, different models for program development, trends and current issues. The session will also describe the federal grant-matching program under Title III of the Tech Act to assist conference participants in successful grant development.

\section{Learning Outcomes:}

\section{Participants will be able to:}

1. Have a basic understanding of assistive technology loan financing programs, their key program components, and practicality as an alternative funding source.

2. Have an awareness of the necessary elements to prepare for the federal Title III grant program intended to assist states and territories in establishing such programs. 